\title{
Awareness and knowledge of sexually transmitted diseases (STDs) among school-going adolescents in Europe: a systematic review of published literature
}

\author{
Florence N Samkange-Zeeb", Lena Spallek and Hajo Zeeb
}

\begin{abstract}
Background: Sexually transmitted diseases (STDs) are a major health problem affecting mostly young people, not only in developing, but also in developed countries.

We conducted this systematic review to determine awareness and knowledge of school-going male and female adolescents in Europe of STDs and if possible, how they perceive their own risk of contracting an STD. Results of this review can help point out areas where STD risk communication for adolescents needs to be improved.

Methods: Using various combinations of the terms "STD", "HIV", "HPV", "Chlamydia", "Syphilis", "Gonorrhoea", "herpes", "hepatitis B", "knowledge", "awareness", and "adolescents", we searched for literature published in the PubMed database from 01.01.1990 up to 31.12.2010. Studies were selected if they reported on the awareness and/ or knowledge of one or more STD among school-attending adolescents in a European country and were published in English or German. Reference lists of selected publications were screened for further publications of interest. Information from included studies was systematically extracted and evaluated.

Results: A total of 15 studies were included in the review. All were cross-sectional surveys conducted among school-attending adolescents aged 13 to 20 years. Generally, awareness and knowledge varied among the adolescents depending on gender.

Six STDs were focussed on in the studies included in the review, with awareness and knowledge being assessed in depth mainly for HIV/AIDS and HPV, and to some extent for chlamydia. For syphilis, gonorrhoea and herpes only awareness was assessed. Awareness was generally high for HIV/AIDS (above 90\%) and low for HPV (range 5.4\%$66 \%)$. Despite knowing that use of condoms helps protect against contracting an STD, some adolescents still regard condoms primarily as an interim method of contraception before using the pill.

Conclusion: In general, the studies reported low levels of awareness and knowledge of sexually transmitted diseases, with the exception of HIV/AIDS. Although, as shown by some of the findings on condom use, knowledge does not always translate into behaviour change, adolescents' sex education is important for STD prevention, and the school setting plays an important role. Beyond HIV/AIDS, attention should be paid to infections such as chlamydia, gonorrhoea and syphilis.
\end{abstract}

\section{Background}

Sexually transmitted diseases (STDs) are a major health problem affecting mostly young people, not only in developing, but also in developed countries.

Over the period 1985-1996, a general decrease of gonorrhoea, syphilis and chlamydia infections was noted

\footnotetext{
* Correspondence: samkange@bips.uni-bremen.de

Bremen Institute for Prevention Research and Social Medicine, University of
} Bremen, Germany

(C) 2011 Samkange-Zeeb et al; licensee BioMed Central Ltd. This is an Open Access article distributed under the terms of the Creative Commons Attribution License (http://creativecommons.org/licenses/by/2.0), which permits unrestricted use, distribution, and reproduction in any medium, provided the original work is properly cited. in developed countries, both in the general population and among adolescents [1]. From the mid-1990s however, increases in the diagnoses of sexually transmitted diseases, in particular syphilis, gonorrhoea and chlamydia have been reported in several European countries, especially among teenagers 16-19 years old [2-7].

The problem with most STDs is that they can occur symptom-free and can thus be passed on unaware during unprotected sexual intercourse. On an individual level, complications can include pelvic inflammatory diseases 
and possibly lead to ectopic pregnancies and infertility [8-11]. Female adolescents are likely to have a higher risk of contracting an STD than their male counterparts as their partners are generally older and hence more likely to be infected $[2,12]$.

The declining age of first sexual intercourse has been proffered as one possible explanation for the increase in numbers of STDs [7]. According to data from different European countries, the average age of first sexual intercourse has decreased over the last three decades, with increasing proportions of adolescents reporting sexual activity before the age of 16 years [13-18]. An early onset of sexual activity not only increases the probability of having various sexual partners, it also increases the chances of contracting a sexually transmitted infection [19]. The risk is higher for female adolescents as their cervical anatomic development is incomplete and especially vulnerable to infection by certain sexually transmitted pathogens [20-23].

The reluctance of adolescents to use condoms is another possible explanation for the increase in STDs. Some surveys of adolescents have reported that condoms were found to be difficult to use for sexually inexperienced, detract from sensual pleasure and also embarrassing to suggest [24-26]. Condoms have also been reported to be used primarily as a protection against pregnancy, not STD, with their use becoming irregular when other contraceptives are used [15,27]. Furthermore, many adolescents do not perceive themselves to be at risk of contracting an STD [27].

We conducted this systematic review in order to determine awareness and knowledge of school-going adolescents in Europe of sexually transmitted diseases, not only concerning HIV/AIDS, but also other STDs such as chlamydia, gonorrhoea, syphilis and human papillomavirus (HPV). Where possible we will identify differences in awareness and knowledge by key demographic variables such as age and gender, and how awareness has changed over time.

Although knowledge and awareness have been reported to have a limited effect on changing attitudes and behaviour, [16,28-30] they are important components of sex education which help promote informed, healthy choices [31-33]. As schooling in Europe is generally compulsory at least up to the age of 15 years [34] and sex education is part of the school curriculum in almost all European countries, school-going adolescents should be well informed on the health risks associated with sexual activity and on how to protect themselves and others. In view of the decreasing age of sexual debut and the reported increasing numbers of diagnosed STDs among young people, results of our review can help point out areas where STD risk communication for school-attending adolescents needs to be improved.

\section{Methods}

\section{Search strategy}

We performed literature searches in PubMed using various combinations of the search terms "STD", "HIV", "HPV", "chlamydia", "syphilis", "gonorrhoea", "herpes", "hepatitis B", "knowledge", "awareness", and "adolescents". The reference lists of selected publications were perused for further publications of interest. The search was done to include articles published from 01.01.1990 up to 31.12.2010. Inclusion and exclusion criteria were specified in advance and documented in a protocol (Additional File 1).

\section{Inclusion criteria}

Studies were selected if they reported on awareness and/or knowledge of one or more sexually transmitted disease(s) among school-attending adolescents in a European country, or in Europe as a whole, and were published in English or German.

\section{Exclusion criteria}

Case reports, reviews, editorials, letters to the editor, expert opinions, studies on sexual activity/behaviour only, studies evaluating intervention programmes and studies not specifically on school-attending adolescents were excluded.

\section{Methodological assessment of reviewed studies}

We used a modified version of the Critical Appraisal Form from the Stanford School of Medicine to assess the methodology of the studies included in the review [35]. The studies were classified according to whether or not they fulfilled given criteria such as 'Were the study outcomes to be measured clearly defined?', 'Was the study sample clearly defined?', or 'Is it clear how data were collected?' (Table 1). No points were allocated. Instead, the following categorisations could be selected for each assessment statement: 'Yes', 'Substandard', 'No', 'Not Clear', 'Not Reported', 'Partially Reported', 'Not Applicable', 'Not Possible to Assess', 'Partly'. The assessment was done independently by two of the authors (FSZ, LS) who then discussed their findings.

\section{Definition of awareness and knowledge}

For the purpose of this review studies were said to have assessed awareness if participants were merely required to identify an STD from a given list or name an STD in response to an open question. Knowledge assessment was when further questions such as on modes of transmission and protection were posed.

\section{Results}

Overall, 465 titles and abstracts were obtained from the searches conducted. Three hundred and ninety-three articles were excluded as they did not report on studies 


\begin{tabular}{|c|c|c|c|c|c|c|c|c|c|}
\hline \multirow[b]{2}{*}{ Criteria } & \multicolumn{9}{|c|}{$\begin{array}{c}\text { Number of studies in each assessment } \\
\text { category* }\end{array}$} \\
\hline & $\mathrm{Y}$ & $\mathrm{S}$ & $\mathrm{N}$ & NC & NR & PR & NA & NP & $\mathbf{P}$ \\
\hline Did the study address a clearly focused issue? & 15 & & & & & & & & \\
\hline Was/were the study outcome(s) to be measured clearly described? & 15 & & & & & & & & \\
\hline Were the questions posed to assess outcome(s) clearly defined? & 14 & & 1 & & & & & & \\
\hline Was the study samle clearly defined? & 13 & & & & & & & & 2 \\
\hline Were participating schools recruited in an acceptable way? & 4 & 1 & & 1 & & & 1 & 8 & \\
\hline Were the pupils recruited in an acceptable way? ${ }^{1}$ & 11 & & & 4 & & & & & \\
\hline Were characteristics of subjects at enrolment reported? & 12 & & 1 & & & & & & 2 \\
\hline Is it clear how data were collected? & 15 & & & & & & & & \\
\hline Did the authors mention that the instrument used for data collection was pre-tested or validated? & 8 & & 6 & & & & & & 1 \\
\hline Were the questions posed appropriate to address given outcomes? & 10 & & & 1 & & & & 4 & \\
\hline Was participation rate reported? & 9 & & & 2 & 4 & & & & \\
\hline Was participation rate sufficiently high? & 7 & 1 & 1 & & & & & 6 & \\
\hline Was the data analysis sufficiently rigorous? & 15 & & & & & & & & \\
\hline Were other factors accounted for that could affect outcomes? ${ }^{2}$ & 15 & & & & & & & & \\
\hline Were results appropriately reported? ${ }^{3}$ & 11 & 1 & & & & & & & 3 \\
\hline Is there a clear statement of findings? & 15 & & & & & & & & \\
\hline
\end{tabular}

conducted in Europe (Figure 1). A further 47 were excluded as they did not focus on knowledge and awareness of adolescents. Of the 25 identified articles dealing with knowledge on STDs among adolescents in Europe, 8 were excluded as they either did not specifically address the question of knowledge and/or awareness, or focused more on sexual behaviour/beliefs. A further seven articles were excluded because the study population was not clearly stated to be school-attending.

A review of the references listed in the 10 articles meeting inclusion criteria yielded four additional relevant articles. One article reported on two studies, hence a total of 15 studies published from 1990-2000 were included in the systematic review.

Six of the articles were published before the year 2000 [36-41], and nine after 2000 [42-49]. The studies report on surveys conducted from as early as 1986 to 2005 (Table 2).

The majority of the 15 studies specifically focused on HIV/AIDS only (7 studies) [36,39,41,43,44,49], four on STDs in general $[37,38,40,42]$, one on STDs in general with focus on HPV [47], and three on HPV only $[45,46,48]$. All the HPV studies were published after the approval and market introduction of the HPV vaccine in 2006.

Generally the studies were conducted in particular regions/towns in different countries, with only one being conducted across three towns in three different countries (Russia, Georgia and the Ukraine) [43]. Six of the studies were conducted in Sweden $[37,38,40,41,46,47]$ two in Russia [39,43] and one each in Ireland, [36] England, [42] Croatia, [44] Finland, [45] Italy [48] and Germany [49] (Table 2).

In the studies, generally both male and female adolescents varying in age from 13-20 years were surveyed. One study surveyed females only [40] and adolescents 11-12 years old were included in only one study [49] (Table 2). Whereas most of the studies included assessed awareness and knowledge among boys and girls separately, only one study [48] specifically assessed the association between age and awareness/knowledge.

\section{Methodological summary of studies included in the review}

All studies included in the review were cross-sectional in design. Apart from one study which recruited pupils by mailing the questionnaire to all households with adolescents in the $9^{\text {th }}$ grade, [45] pupils were recruited via schools. For 8 of the 15 studies it could not be deduced from the methods section how the participating schools were selected and in 4 studies it was not clear how the participating pupils were selected. The pupils completed questionnaires in school in 10 studies, and in two the questionnaires were completed at home $[45,48]$. 


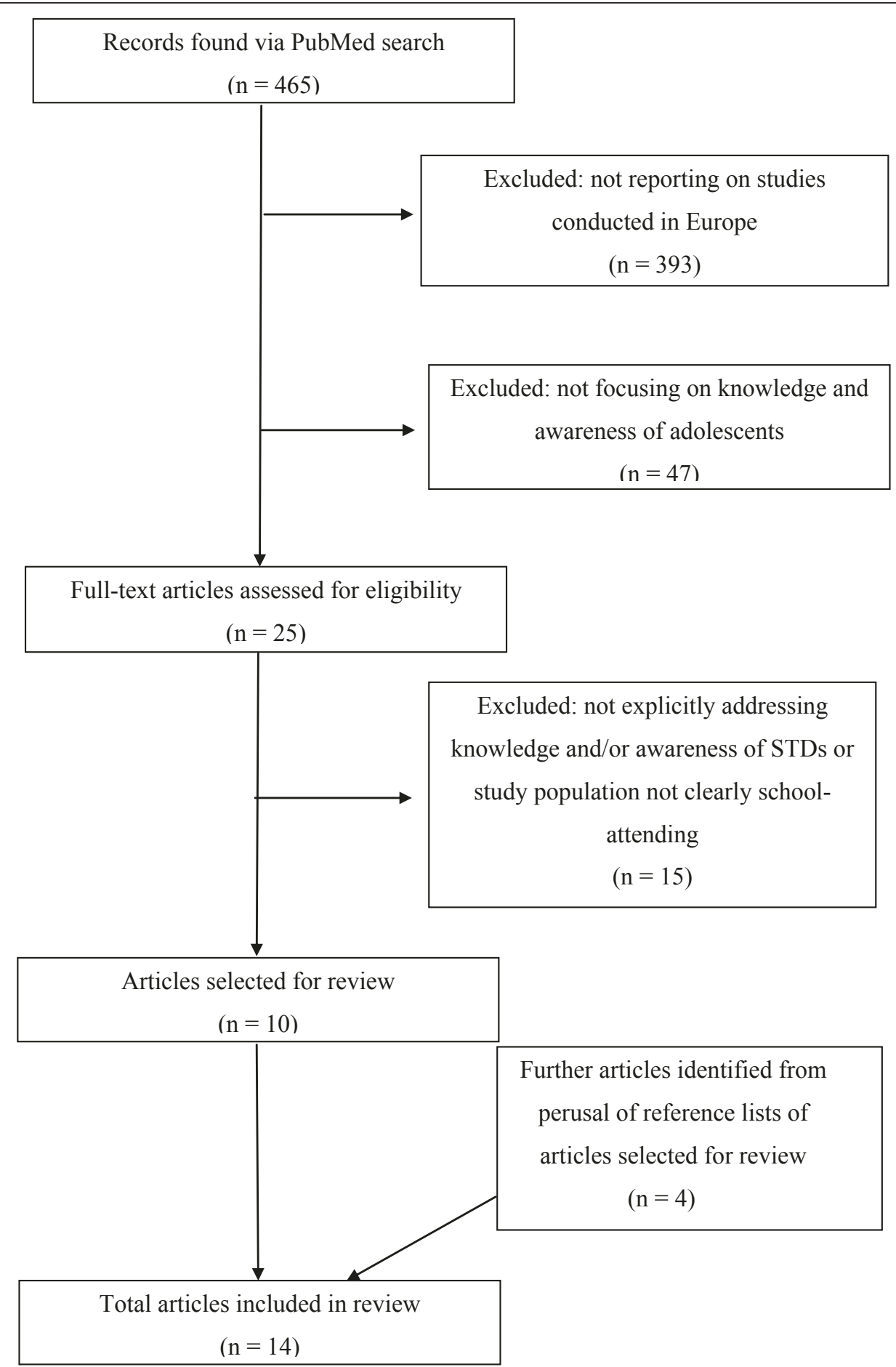

Figure 1 Flow diagram showing selection process of articles included in the review

Face-to-face interviews were used only in the surveys by Andersson-Ellström et al. [40] and by Goodwin et al. [43] (Table 2).

The study outcomes were clearly defined in all studies and the topics on which questions were posed were clearly described in all but one study. The majority of the studies also reported the individual questions posed to assess the given outcomes. In six studies the authors did not mention whether the instruments used for data collection had been pre-tested, validated, or whether the questions posed had been used in previous surveys (Table 1). Of the 9 studies which clearly reported 
Table 2 Characteristics of the 15 studies on knowledge on sexually transmitted diseases among school-attending adolescents in Europe

\begin{tabular}{|c|c|c|c|c|c|c|c|c|c|}
\hline Reference & $\begin{array}{l}\text { Study } \\
\text { region, } \\
\text { country }\end{array}$ & $\begin{array}{l}\text { Year of } \\
\text { study } \\
\text { conduct }\end{array}$ & $\begin{array}{l}\text { Survey } \\
\text { instrument }\end{array}$ & $\begin{array}{l}\text { Reported outcome } \\
\text { (s) measured }\end{array}$ & $\begin{array}{l}\text { Age of } \\
\text { participants }\end{array}$ & $\begin{array}{l}\text { No. of } \\
\text { participants }\end{array}$ & Gender & $\begin{array}{l}\text { Recruitment } \\
\text { of pupils }\end{array}$ & $\begin{array}{l}\text { Response } \\
\text { rate }\end{array}$ \\
\hline Fogarty [36] & $\begin{array}{l}\text { Galway, } \\
\text { Ireland }\end{array}$ & $\begin{array}{l}\text { Not } \\
\text { available }\end{array}$ & $\begin{array}{l}\text { Classroom- } \\
\text { completed } \\
\text { questionnaire }\end{array}$ & $\begin{array}{l}\text { Knowledge about } \\
\text { AIDS }\end{array}$ & $15-18$ years & $\begin{array}{l}2614 \text { leaving } \\
\text { certificate } \\
\text { pupils }\end{array}$ & $\begin{array}{l}\text { Male/ } \\
\text { female }\end{array}$ & $\begin{array}{l}\text { All } 50 \text { Galway } \\
\text { second-level } \\
\text { schools }\end{array}$ & $\begin{array}{l}\text { Not } \\
\text { available }\end{array}$ \\
\hline $\begin{array}{l}\text { Andersson- } \\
\text { Ellström et al. } \\
\text { [37] }\end{array}$ & $\begin{array}{l}\text { Not specified, } \\
\text { Sweden }\end{array}$ & $\begin{array}{l}1986 \\
\text { and } \\
1988\end{array}$ & $\begin{array}{l}\text { Classroom- } \\
\text { completed } \\
\text { questionnaire }\end{array}$ & $\begin{array}{l}\text { Knowledge of and } \\
\text { attitudes towards } \\
\text { STDs }\end{array}$ & 18-19 years & $\begin{array}{l}\text { 1986: } 350 \\
\text { 1988: } 603 \\
\text { upper } \\
\text { secondary } \\
\text { school } \\
\text { pupils }\end{array}$ & $\begin{array}{l}\text { Male/ } \\
\text { female }\end{array}$ & $\begin{array}{l}\text { Not clear how } \\
\text { many schools } \\
\text { participated }\end{array}$ & $100 \%$ \\
\hline $\begin{array}{l}\text { Tyden et al. } \\
\text { [38] }\end{array}$ & $\begin{array}{l}\text { Uppsala, } \\
\text { Sweden }\end{array}$ & 1988 & $\begin{array}{l}\text { Classroom- } \\
\text { completed } \\
\text { questionnaire }\end{array}$ & $\begin{array}{l}\text { Knowledge of STDs } \\
\text { and attitudes to } \\
\text { condom }\end{array}$ & 16-19 years & $\begin{array}{l}209 \text { year } 1 \\
\text { of upper } \\
\text { secondary } \\
\text { school } \\
\text { pupils }\end{array}$ & $\begin{array}{l}\text { Male/ } \\
\text { female }\end{array}$ & $\begin{array}{l}5 \text { of } 6 \text { upper } \\
\text { secondary } \\
\text { schools }\end{array}$ & $98 \%$ \\
\hline $\begin{array}{l}\text { Lunin et al. } \\
\text { [39] }\end{array}$ & $\begin{array}{l}\text { St. } \\
\text { Petersburg, } \\
\text { Russia }\end{array}$ & 1993 & $\begin{array}{l}\text { Classroom- } \\
\text { completed } \\
\text { questionnaire }\end{array}$ & $\begin{array}{l}\text { Knowledge, attitudes } \\
\text { and behaviour } \\
\text { relevant to AIDS } \\
\text { prevention }\end{array}$ & $14-17$ years & $\begin{array}{l}370 \text { year } 10 \\
\text { pupils }\end{array}$ & $\begin{array}{l}\text { Male/ } \\
\text { female }\end{array}$ & $\begin{array}{l}14 \text { randomly } \\
\text { selected } \\
\text { schools }\end{array}$ & $94 \%$ \\
\hline $\begin{array}{l}\text { Andersson- } \\
\text { Ellström et al. } \\
{[40]}\end{array}$ & $\begin{array}{l}\text { Karlstad, } \\
\text { Sweden }\end{array}$ & $\begin{array}{l}1989- \\
1990\end{array}$ & $\begin{array}{l}\text { Questionnaire } \\
\text { completed at } \\
\text { clinic }\end{array}$ & $\begin{array}{l}\text { Relationship } \\
\text { between knowledge } \\
\text { about STD, sexual } \\
\text { behaviour, } \\
\text { contraceptive use, } \\
\text { STD protection and } \\
\text { social class }\end{array}$ & $16-18$ years & $\begin{array}{l}88 \text { year } 1 \text { of } \\
\text { upper } \\
\text { secondary } \\
\text { school } \\
\text { pupils }\end{array}$ & Female & $\begin{array}{l}\text { Not clear how } \\
\text { many schools } \\
\text { participated }\end{array}$ & $58 \%$ \\
\hline $\begin{array}{l}\text { Eriksson et al. } \\
{[41]^{*}}\end{array}$ & $\begin{array}{l}\text { Not specified, } \\
\text { Sweden }\end{array}$ & 1994 & $\begin{array}{l}\text { Classroom- } \\
\text { completed } \\
\text { questionnaire }\end{array}$ & $\begin{array}{l}\text { Knowledge on HIV/ } \\
\text { AIDS and sources of } \\
\text { information }\end{array}$ & 14-16 years & $\begin{array}{l}146 \text { year } 9 \\
\text { pupils }\end{array}$ & $\begin{array}{l}\text { Male/ } \\
\text { female }\end{array}$ & 1 school & $100 \%$ \\
\hline $\begin{array}{l}\text { Garside et al. } \\
{[42]^{* *}}\end{array}$ & $\begin{array}{l}\text { Devon, } \\
\text { England }\end{array}$ & $\begin{array}{l}1999- \\
2000\end{array}$ & $\begin{array}{l}\text { Classroom- } \\
\text { completed } \\
\text { questionnaire }\end{array}$ & $\begin{array}{l}\text { Knowledge and } \\
\text { attitudes towards } \\
\text { STDs, their detection } \\
\text { and treatment }\end{array}$ & $13-16$ years & $\begin{array}{l}432 \text { year } 9 \\
\text { and } 11 \\
\text { pupils }\end{array}$ & $\begin{array}{l}\text { Male/ } \\
\text { female }\end{array}$ & 1 school & $\begin{array}{l}\text { Not } \\
\text { reported }\end{array}$ \\
\hline $\begin{array}{l}\text { Goodwin et al. } \\
{[43]^{1}}\end{array}$ & $\begin{array}{l}\text { St. } \\
\text { Petersburg, } \\
\text { Russia; }\end{array}$ & 2000 & $\begin{array}{l}\text { Face-face } \\
\text { interview in } \\
\text { school }\end{array}$ & $\begin{array}{l}\text { Knowledge on HIV/ } \\
\text { AIDS, sexual } \\
\text { behaviour }\end{array}$ & $\begin{array}{l}\text { Mean age } \\
15.6 \text { years }\end{array}$ & $\begin{array}{l}50 \text { school } \\
\text { pupils }\end{array}$ & $\begin{array}{l}\text { Male/ } \\
\text { female }\end{array}$ & $\begin{array}{l}\text { Not clear how } \\
\text { many schools } \\
\text { participated }\end{array}$ & Not clear \\
\hline $\begin{array}{l}\text { Goodwin et al. } \\
{[43]^{2}}\end{array}$ & $\begin{array}{l}\text { St. } \\
\text { Petersburg, } \\
\text { Russia; Tblisi, } \\
\text { Georgia; Kiev, } \\
\text { Ukraine }\end{array}$ & $\begin{array}{l}\text { Not } \\
\text { available }\end{array}$ & $\begin{array}{l}\text { Face-face } \\
\text { interview in } \\
\text { school and } \\
\text { classroom- } \\
\text { completed } \\
\text { questionnaire }\end{array}$ & $\begin{array}{l}\text { Knowledge on HIV/ } \\
\text { AIDS, sexual } \\
\text { behaviour }\end{array}$ & 14-17 years & $\begin{array}{l}102 \text { school } \\
\text { pupils }\end{array}$ & $\begin{array}{l}\text { Male/ } \\
\text { female }\end{array}$ & $\begin{array}{l}\text { Not clear how } \\
\text { many schools } \\
\text { participated }\end{array}$ & Not clear \\
\hline $\begin{array}{l}\text { Macek et al. } \\
{[44]}\end{array}$ & $\begin{array}{l}\text { Nova } \\
\text { Gradiska/ } \\
\text { Zagreb, } \\
\text { Croatia }\end{array}$ & $\begin{array}{l}\text { Not } \\
\text { available }\end{array}$ & $\begin{array}{l}\text { Classroom- } \\
\text { completed } \\
\text { questionnaire }\end{array}$ & $\begin{array}{l}\text { Knowledge on HIV/ } \\
\text { AIDS, attitudes } \\
\text { towards integration } \\
\text { of HIV-positive pupils } \\
\text { into regular schools }\end{array}$ & $\begin{array}{l}\text { Not } \\
\text { available }\end{array}$ & $\begin{array}{l}108 \text { year } 7 \\
\text { and } 8 \text { pupils }\end{array}$ & $\begin{array}{l}\text { Male/ } \\
\text { female }\end{array}$ & 2 schools & $\begin{array}{l}\text { Not } \\
\text { reported }\end{array}$ \\
\hline $\begin{array}{l}\text { Woodhall et al. } \\
{[45]^{* * *}}\end{array}$ & $\begin{array}{l}\text { Tampere, } \\
\text { Finland }\end{array}$ & 2005 & $\begin{array}{l}\text { Home- } \\
\text { completed } \\
\text { questionnaire }\end{array}$ & $\begin{array}{l}\text { Knowledge of and } \\
\text { attitudes towards } \\
\text { STDs, esp. HPV }\end{array}$ & 14-15 years & $\begin{array}{l}397 \text { year } 9 \\
\text { pupils }\end{array}$ & $\begin{array}{l}\text { Male/ } \\
\text { female }\end{array}$ & $\begin{array}{l}\text { All households } \\
\text { in Tampere } \\
\text { with } \\
\text { adolescents } \\
\text { born in } 1990 \\
\text { and in year } 9 \\
\text { contacted }\end{array}$ & $21.5 \%$ \\
\hline $\begin{array}{l}\text { Gottvall et al. } \\
\text { [46] }\end{array}$ & $\begin{array}{l}\text { Not specific, } \\
\text { Sweden }\end{array}$ & 2008 & $\begin{array}{l}\text { Classroom- } \\
\text { completed } \\
\text { questionnaire }\end{array}$ & $\begin{array}{l}\text { Knowledge of and } \\
\text { attitudes towards } \\
\text { HPV vaccination and } \\
\text { condom use }\end{array}$ & $15-16$ years & $\begin{array}{l}608 \text { year } 1 \\
\text { of upper } \\
\text { secondary } \\
\text { school } \\
\text { pupils }\end{array}$ & $\begin{array}{l}\text { Male/ } \\
\text { female }\end{array}$ & 7 schools & $86 \%$ \\
\hline
\end{tabular}


Table 2 Characteristics of the 15 studies on knowledge on sexually transmitted diseases among school-attending adolescents in Europe (Continued)

\begin{tabular}{|c|c|c|c|c|c|c|c|c|c|}
\hline $\begin{array}{l}\text { Höglund et al. } \\
\text { [47] }\end{array}$ & $\begin{array}{l}\text { Uppsala, } \\
\text { Sweden }\end{array}$ & $\begin{array}{l}\text { Not } \\
\text { available }\end{array}$ & $\begin{array}{l}\text { Classroom- } \\
\text { completed } \\
\text { questionnaire }\end{array}$ & $\begin{array}{l}\text { Knowledge of and } \\
\text { attitudes to STDs, } \\
\text { focus on HPV }\end{array}$ & $15-20$ years & $\begin{array}{l}459 \text { year } 1 \\
\text { of upper } \\
\text { secondary } \\
\text { school } \\
\text { pupils }\end{array}$ & $\begin{array}{l}\text { Male/ } \\
\text { female }\end{array}$ & 5 schools & $98 \%$ \\
\hline $\begin{array}{l}\text { Pelucchi et al. } \\
{[48]^{* * *}}\end{array}$ & $\begin{array}{l}\text { Milan area } \\
\text { and Varese, } \\
\text { Italy }\end{array}$ & 2008 & $\begin{array}{l}\text { Home- } \\
\text { completed } \\
\text { questionnaire }\end{array}$ & $\begin{array}{l}\text { Knowledge of HPV, } \\
\text { prevention, and } \\
\text { attitudes towards } \\
\text { vaccination }\end{array}$ & $14-20$ years & $\begin{array}{l}863 \text { high } \\
\text { school } \\
\text { pupils }\end{array}$ & $\begin{array}{l}\text { Male/ } \\
\text { female }\end{array}$ & 8 schools & $79 \%$ \\
\hline $\begin{array}{l}\text { Sachsenweger } \\
\text { et al.[49] }\end{array}$ & $\begin{array}{l}\text { Mecklenburg- } \\
\text { Western } \\
\text { Pomerania, } \\
\text { Germany }\end{array}$ & 2005 & $\begin{array}{l}\text { Classroom- } \\
\text { completed } \\
\text { questionnaire }\end{array}$ & $\begin{array}{l}\text { Knowledge on HIV/ } \\
\text { AIDS }\end{array}$ & $11-18$ years & $\begin{array}{l}769 \text { year } 7-9 \\
\text { pupils }\end{array}$ & $\begin{array}{l}\text { Male/ } \\
\text { female }\end{array}$ & $\begin{array}{l}\text { Not clear how } \\
\text { many schools } \\
\text { participated }\end{array}$ & $\begin{array}{l}\text { Not } \\
\text { available }\end{array}$ \\
\hline
\end{tabular}

* Other part of study conducted in Kenya. Only Swedish part reported on and included in this review.

** Focus group discussions also held with local teenagers. Only details pertaining to questionnaire survey reported on and included in this review.

1,2 Publication reported on two separate studies. In both school children were compared to shelter children. Only details pertaining to school children are reported on and included in this review.

*** Questionnaires also sent to parents. Only details pertaining to adolescents reported on and included in this review.

"Publication in German.

participation rates, 7 had participation rates ranging from $79 \%$ to $100 \%$. The remaining two studies had participation rates of $21.5 \%$ and $58 \%$ (Table 2).

Six STDs were focussed on in the studies included in the review, with awareness and knowledge being assessed in depth mainly for HIV/AIDS and HPV, [36,41-43,46-49] and to some extent for chlamydia $[37,38,42,47]$. For syphilis, gonorrhoea and herpes, only awareness was assessed in four studies $[37,38,42,47]$.

\section{Awareness and knowledge of HPV}

The reported awareness of HPV among the surveyed adolescents was generally low (identification from given list), ranging from $5.4 \%$ in the study by Höglund et al. [47] to $66 \%$ in the study by Pelucchi et al. [48]. In the two studies which also reported results for females and males separately, awareness was observed to be statistically significantly higher among females than among males: $16.4 \%$ vs. $9.6 \%$ in the Swedish study by Gottvall et al. [46] and $71.6 \%$ vs. $51.2 \%$ in the Italian study by Pelucchi et al. [48]. In the study by Höglund et al., only one of the participating 459 adolescents mentioned HPV (in response to an open question on known STDs) [47].

Awareness of the HPV vaccine was also very low, with $5.8 \%$ and $1.1 \%$ of adolescents surveyed in the studies by Gottvall et al. and Höglund et al. respectively, reporting being aware of the vaccine [46,47]. Whereas only $2.9 \%$ and $9.2 \%$ of adolescents in these two Swedish studies were aware that HPV is sexually transmitted, the proportion was $60.6 \%$ in the Italian study [48]. A minority of adolescents knew that HPV is a risk factor for cervical cancer: $1.2 \%$ in the study by Höglund et al. [47] and $8.1 \%$ in the study by Gottvall et al. [46]. Among the adolescents who participated in the survey by Pelucchi et al., $48.6 \%$ were aware that the aim of the HPV vaccine is to prevent cervical cancer [48]. Among female adolescents who participated in the study by Gottvall et al., $11.8 \%$ did not believe they would be infected with HPV [46]. The proportion was $55 \%$ among female participants in the study by Pelucchi et al. [48]. The latter study surveyed pupils aged 14-20 years but did not report on age differences in awareness.

Three studies reported on awareness of condylomata, genital warts which are caused by the human papilloma virus. Two of the studies reported awareness of $35 \%$ [38] and 43\% [37]. The third study mentioned that awareness of condylomata was lower than that for chlamydia without stating the corresponding figures [40].

\section{Awareness and knowledge of HIV/AIDS}

Knowledge and awareness was quite high in all studies reporting on HIV/AIDS, with more than $90 \%$ of adolescents being able to identify the disease as an STD from a given list or in response to the direct question "Have you ever heard of HIV/AIDS?" [36,38,42]. In one study where the open question "Which STDs do you know or have you heard of?" was used, $88 \%$ of respondents mentioned HIV/AIDS [47] (Table 3).

In the studies where this was asked, a large majority of the adolescents knew that HIV is caused by a virus, $[36,41]$ is sexually transmitted, $[36,41,43,47,49]$ and that sharing a needle with an infected person may lead to infection with the virus $[36,41,43,49]$. Statistically significant age specific differences in knowledge on mode of HIV-transmission were reported in the study conducted in Germany [49]. Compared to 13 and 15 year old pupils, a higher proportion of 14 year old pupils correctly identified the level of risk of HIV-transmission associated with bleeding wounds, intravenous drug use and sexual 
Table 3 Awareness and knowledge of STDs reported in 14 of the 15 studies included in the review

\begin{tabular}{|c|c|c|c|}
\hline Question/Item assessed in studies & $\begin{array}{l}\text { Females } \\
\% \text { (reference) }\end{array}$ & $\begin{array}{l}\text { Males } \\
\% \text { (reference) }\end{array}$ & $\begin{array}{l}\text { Females and males } \\
\% \text { (reference) }\end{array}$ \\
\hline \multicolumn{4}{|l|}{$\mathrm{HPV}$} \\
\hline $\begin{array}{l}\text { Heard of HPV (identification from list of STDs or } \\
\text { direct question, 'Have you heard of HPV?') }\end{array}$ & $\begin{array}{l}\text { 71.6\% (Pelucchi et al.) [49] } \\
16.4 \% \text { (Gottvall et al.) [46] }\end{array}$ & $\begin{array}{l}\text { 51.2\% (Pelucchi et al.) [49] } \\
\text { 9.6\% (Gottvall et al., 2009) [46] }\end{array}$ & $\begin{array}{l}\text { 66.6\% (Pelucchi et al..) }{ }^{* *}[49] \\
\text { 13.5\% (Gottvall et al.) }{ }^{* *}[46] \\
5.4 \% \text { (Höglund et al.) }[47] \\
\text { 33\% (Woodhall et al.) }[45]\end{array}$ \\
\hline $\begin{array}{l}\text { Heard of HPV (open question - 'Which STDs do } \\
\text { you know/have you heard of?') }\end{array}$ & & & $0.2 \%$ (Höglund et al.) [47] \\
\hline Heard of HPV vaccine & 9.2\% (Gottvall et al.) [46] & 1.1\% (Gottvall et al.) [46] & $\begin{array}{l}5.8 \% \text { (Gottvall et al.)** }[46] \\
1.1 \% \text { (Höglund et al.) }[47]\end{array}$ \\
\hline $\begin{array}{l}\text { Participants who knew that HPV is sexually } \\
\text { transmitted }\end{array}$ & $\begin{array}{l}\text { 64.9\% (Pelucchi et al.) [49] } \\
12.1 \% \text { (Gottvall et al.) [46] }\end{array}$ & $\begin{array}{l}\text { 47.4\% (Pelucchi et al.) [49] } \\
5.4 \% \text { (Gottvall et al.) [46] }\end{array}$ & $\begin{array}{l}\text { 60.6\% (Pelucchi et al.) [49] } \\
9.2 \% \text { (Gottvall et al.)** [46] } \\
2.9 \% \text { (Höglund et al.) [47] }\end{array}$ \\
\hline $\begin{array}{l}\text { Participants who knew that HPV is a risk factor } \\
\text { for cervical cancer (closed question) }\end{array}$ & $11.8 \%$ (Gottvall et al.) [46] & 3.1\% (Gottvall et al.) [46] & $\begin{array}{l}\text { 8.1\% (Gottvall et al.) [46] } \\
1.2 \% \text { (Höglund et al.) [47] }\end{array}$ \\
\hline $\begin{array}{l}\text { Participants aware that aim of HPV vaccination } \\
\text { is to prevent cervical cancer }\end{array}$ & 53.9\% (Pelucchi et al.) [49] & 32.1\% (Pelucchi et al.) [49] & 48.6\% (Pelucchi et al.)** [49] \\
\hline $\begin{array}{l}\text { Participants who thought that aim of HPV } \\
\text { vaccination is to prevent an STD }\end{array}$ & 8.6\% (Pelucchi et al.) [49] & 7.2\%(Pelucchi et al., 2010) [49] & 8.3\% (Pelucchi et al.) [49] \\
\hline Subjective rating of risk of contracting HPV & $\begin{array}{l}45 \% \text { perceived at risk (Pelucchi } \\
\text { et al.) [49] } \\
11.8 \% \text { do not believe will be } \\
\text { infected (Gottvall et al.) [46] }\end{array}$ & $\begin{array}{l}\text { 26\% perceived at risk (Pelucchi } \\
\text { et al.) [49] } \\
24.5 \% \text { do not believe will be } \\
\text { infected (Gottvall et al.) [46] }\end{array}$ & $\begin{array}{l}\text { 17.3\% do not believe will be } \\
\text { infected (Gottvall et al..)* }\end{array}$ \\
\hline \multicolumn{4}{|l|}{ HIV } \\
\hline $\begin{array}{l}\text { Heard of HIV (identification from list of STDs or } \\
\text { direct question) }\end{array}$ & $\begin{array}{l}\text { 97.2\% among year } 9 \text { and } 100 \% \\
\text { among year } 11 \text { pupils (Garside } \\
\text { et al.) [42] }\end{array}$ & $\begin{array}{l}\text { 97.0\% among year } 9 \text { and } 96.2 \% \\
\text { among year } 11 \text { pupils (Garside } \\
\text { et al.) [42] }\end{array}$ & $\begin{array}{l}\text { 97.7\% (Garside et al.) [42] } \\
\text { 100\% (Tyden et al.) } 91 \% \text { [38] } \\
\text { (Fogarty) [36] }\end{array}$ \\
\hline $\begin{array}{l}\text { Heard of HIV (open question - which STDs do } \\
\text { you know/have you heard of?) }\end{array}$ & & & 88\% (Höglund et al.) [47] \\
\hline $\begin{array}{l}\text { Participants who knew that you can not tell by } \\
\text { looking at someone if they have HIV }\end{array}$ & & & $\begin{array}{l}\text { Overall 53\% (Goodwin et al.) })^{2} \\
\text { [43] }\end{array}$ \\
\hline $\begin{array}{l}\text { Participants who knew that HIV is caused by a } \\
\text { virus }\end{array}$ & & & $\begin{array}{l}\text { 91\% (Eriksson et al.) [41] } \\
88 \% \text { (Fogarty) [36] }\end{array}$ \\
\hline $\begin{array}{l}\text { Participants who knew that HIV is sexually } \\
\text { transmitted }\end{array}$ & $\begin{array}{l}\text { 99\% (Sachsenweger et al.) } \# \\
{[49]} \\
97 \%(\text { Goodwin et al.) })^{1}[43]\end{array}$ & $\begin{array}{l}\text { 99\% (Sachsenweger et al.). }{ }^{\#[49]} \\
86 \% \text { (Goodwin et al..) }{ }^{1}[43]\end{array}$ & $\begin{array}{l}99 \% \text { (Sachsenweger et al.) } \#[49] \\
81 \% \text { (Höglund et al.) [47] } \\
92 \% \text { (Goodwin et al..) }{ }^{1}[43] \\
\text { 99\% (Eriksson et al.) [41] } \\
\text { 95\% (Fogarty) [36] }\end{array}$ \\
\hline $\begin{array}{l}\text { Participants who knew that sharing a needle } \\
\text { with an HIV infected person may lead to } \\
\text { infection with the virus }\end{array}$ & $\begin{array}{l}\text { 91\% (Sachsenweger et al.) }{ }^{\#}[49] \\
72 \% \text { (Goodwin et al..) }{ }^{1}[43]\end{array}$ & $\begin{array}{l}\text { 91\% (Sachsenweger et al.). }{ }^{\#[49]} \\
62 \% \text { (Goodwin et al..) }{ }^{1}[43]\end{array}$ & $\begin{array}{l}\text { 91\% (Sachsenweger et al..) }{ }^{\#}[49] \\
68 \% \text { (Goodwin et al..) }{ }^{1}[43] \\
95 \% \text { (Eriksson et al.) }[41] \\
\text { 99\% (Fogarty) [36] }\end{array}$ \\
\hline $\begin{array}{l}\text { Participants who knew that use of condoms } \\
\text { can protect against contraction of HIV }\end{array}$ & $\begin{array}{l}\text { 83\%(Goodwin et al.) }{ }^{1}[43] \\
42 \% \text { (Lunin et al.) [39] }\end{array}$ & $\begin{array}{l}\text { 86\% (Goodwin et al.) }{ }^{1}[43] \\
60 \% \text { (Lunin et al.) [39] }\end{array}$ & $\begin{array}{l}\text { 99\% (Sachsenweger et al.) }{ }^{\#}[49] \\
76 \% \text { (Höglund et al.) [47] } \\
\text { 84\% (Goodwin et al.) }{ }^{1}[43] \\
99 \% \text { (Eriksson et al.) [41] } \\
\text { 51\% (Lunin et al., 1995) }{ }^{* *} \text { [39] } \\
\text { 94\% (Fogarty) [36] }\end{array}$ \\
\hline $\begin{array}{l}\text { Participants who knew where to go for } \\
\text { diagnosis/treatment/advice on HIV }\end{array}$ & & & $\begin{array}{l}22 \% \text { aware of STD clinic and } \\
32 \% \text { of AIDS telephone service } \\
\text { (Fogarty) [36] }\end{array}$ \\
\hline Subjective rating of risk of contracting HIV & $\begin{array}{l}\text { 11\% perceived themselves 'not } \\
\text { at risk' (Lunin et al.) [39] }\end{array}$ & $\begin{array}{l}\text { 19\% perceived themselves 'not } \\
\text { at risk' (Lunin et al.) [39] }\end{array}$ & $\begin{array}{l}\text { 15\% perceived themselves 'not } \\
\text { at risk' (Lunin et al.).** }[39]\end{array}$ \\
\hline \multicolumn{4}{|l|}{ Chlamydia } \\
\hline $\begin{array}{l}\text { Heard of chlamydia (identification from list of } \\
\text { STDs or direct question) }\end{array}$ & $\begin{array}{l}41.4 \% \text { among year } 9 \text { and } 22.7 \% \\
\text { among year } 11 \text { pupils (Garside } \\
\text { et al.) [42] } \\
79 \% \text { (Tyden et al.) [38] }\end{array}$ & $\begin{array}{l}36.7 \% \text { among year } 9 \text { and } 13.2 \% \\
\text { among year } 11 \text { pupils (Garside } \\
\text { et al.) [42] } \\
60 \% \text { (Tyden et al.) [38] }\end{array}$ & $\begin{array}{l}\text { 34\% (Garside et al.)*** [42] } \\
70 \% \text { (Tyden et al.) [38] } \\
91 \% \text { in 1986, and 96\% in } 1988 \\
\text { survey (Andersson-Ellström } \\
\text { et al.) [37] }\end{array}$ \\
\hline $\begin{array}{l}\text { Heard of chlamydia (open question - which } \\
\text { STDs do you know/have you heard of?) }\end{array}$ & & & 86\% (Höglund et al.) [47] \\
\hline
\end{tabular}


Table 3 Awareness and knowledge of STDs reported in 14 of the 15 studies included in the review (Continued)

\begin{tabular}{|c|c|c|c|}
\hline $\begin{array}{l}\text { Participants who knew that chlamydia can be } \\
\text { symptom-free }\end{array}$ & $\begin{array}{l}51 \% \text { in } 1986 \text {, and } 68 \% \text { in } 1988 \\
\text { survey (Andersson-Ellström et } \\
\text { al.) [37] }\end{array}$ & $\begin{array}{l}28 \% \text { in 1986, and } 45 \% \text { in } 1988 \\
\text { survey (Andersson-Ellström et } \\
\text { al.) [37] }\end{array}$ & $\begin{array}{l}46 \% \text { (Höglund et al.) [47] } \\
40 \% \text { in } 1986, \text { and } 56 \% \text { in } 1988 \\
\text { survey (Andersson-Ellström } \\
\text { et al.) }{ }^{* *}[37]\end{array}$ \\
\hline \multicolumn{4}{|l|}{ Syphilis } \\
\hline $\begin{array}{l}\text { Heard of syphilis (identification from list of } \\
\text { STDs or direct question) }\end{array}$ & $\begin{array}{l}45.5 \% \text { among year } 9 \text { and } 47.0 \% \\
\text { among year } 11 \text { pupils (Garside } \\
\text { et al.) [42] }\end{array}$ & $\begin{array}{l}\text { 43.4\% among year } 9 \text { and } 45.3 \% \\
\text { among year } 11 \text { pupils (Garside } \\
\text { et al.) [42] }\end{array}$ & 45\% (Garside et al.) [42] \\
\hline \multicolumn{4}{|l|}{ Gonorrhoea } \\
\hline $\begin{array}{l}\text { Heard of gonorrhoea (identification from list of } \\
\text { STDs or direct question) }\end{array}$ & $\begin{array}{l}51.0 \% \text { among year } 9 \text { and } 53.0 \% \\
\text { among year } 11 \text { pupils (Garside } \\
\text { et al.) [42] }\end{array}$ & $\begin{array}{l}52.4 \% \text { among year } 9 \text { and } 60.4 \% \\
\text { among year } 11 \text { pupils (Garside } \\
\text { et al.) [42] }\end{array}$ & $\begin{array}{l}\text { 53\% (Garside et al.) [42] } \\
\geq 84 \% \text { (Tyden et al.) [38] } \\
\text { 98\%, } 1986 \text { survey (Andersson- } \\
\text { Ellström et al.) [37] }\end{array}$ \\
\hline $\begin{array}{l}\text { Heard of gonorrhoea (open question - which } \\
\text { STDs do you know/have you heard of?) }\end{array}$ & & & 50\% (Höglund et al.) [47] \\
\hline \multicolumn{4}{|l|}{ Herpes } \\
\hline $\begin{array}{l}\text { Heard of herpes (identification from list of STDs } \\
\text { or direct question) }\end{array}$ & $\begin{array}{l}52.4 \% \text { among year } 9 \text { and } 75.8 \% \\
\text { among year } 11 \text { pupils (Garside } \\
\text { et al.) [42] }\end{array}$ & $\begin{array}{l}53.6 \% \text { among year } 9 \text { and } 71.7 \% \\
\text { among year } 11 \text { pupils (Garside } \\
\text { et al.) [42] }\end{array}$ & $\begin{array}{l}\text { 59.1\% (Garside et al..*** [42] } \\
\text { 90\%, } 1986 \text { survey (Andersson- } \\
\text { Ellström et al.) [37] } \\
56 \% \text { (Tyden et al.) [38] }\end{array}$ \\
\hline Heard of herpes (open question - which STDs & & & 64\% (Höglund et al.) [47] \\
\hline
\end{tabular}

do you know/have you heard of?)

\begin{tabular}{|c|c|c|c|}
\hline \multicolumn{4}{|l|}{ STDs in general } \\
\hline \multicolumn{4}{|l|}{ can be symptom-free } \\
\hline $\begin{array}{l}\text { can protect against contraction of STDs in } \\
\text { general }\end{array}$ & $\begin{array}{l}\text { 15\%, } 1986 \text { survey (Andersson- } \\
\text { Ellström et al.) [37] } \\
34 \%, 1988 \text { survey (Andersson- } \\
\text { Ellström et al.) [37] } \\
\text { 100\% (Andersson-Ellström et al.) } \\
{[40]}\end{array}$ & $\begin{array}{l}\text { 27\%, } 1986 \text { survey (Andersson- } \\
\text { Ellström et al.) [37] } \\
52 \%, 1988 \text { survey (Andersson- } \\
\text { Ellström et al.) [37] }\end{array}$ & $\begin{array}{l}\text { 20\%, } 1986 \text { survey (Andersson- } \\
\text { Ellström et al..)** [37] } \\
43 \%, 1988 \text { survey (Andersson- } \\
\text { Ellström et al..)** [37] } \\
100 \% \text { (Tyden et al.) [38] }\end{array}$ \\
\hline $\begin{array}{l}\text { Subjective rating of risk of contracting an STD } \\
\text { in general }\end{array}$ & $\begin{array}{l}\text { 32\%, } 1986 \text { survey (Andersson- } \\
\text { Ellström et al., 1991) [37] } \\
24 \%, 1988 \text { survey (Andersson- } \\
\text { Ellström et al.) [37] }\end{array}$ & $\begin{array}{l}\text { 16\%, } 1986 \text { survey (Andersson- } \\
\text { Ellström et al.) [37] } \\
\text { 24\%, } 1988 \text { survey (Andersson- } \\
\text { Ellström et al.) [37] }\end{array}$ & $\begin{array}{l}\text { 55\% "low" perceived } \\
\text { susceptibility (Woodhall et al.)* } \\
\text { [45] }\end{array}$ \\
\hline
\end{tabular}

\section{Reported use of condoms}

Participants who reported using condoms at 50\% (Tyden et al.) [38] 40\% (Tyden et al.) [38] 45\% (Tyden et al.) [38]

first sexual intercourse 65\% (Gottvall et al.) [46]

Participants who reported using condoms at $\quad$ 26\% (Tyden et al.) [38] 38\% (Tyden et al.) [38]

last sexual intercourse

* combined figure given for HPV and chlamydia

** statistically significant differences in awareness/knowledge between boys and girls

*** statistically significant differences in awareness/knowledge between year 9 and year 11 pupils

\# Publication in German

contact. For the latter mode of transmission, the lowest proportion of correct answers was observed among 16 year old pupils. Generally the proportion of respondents correctly reporting that use of condoms helps protect against contraction of HIV was above $90 \%$. The only exception was in the Russian study conducted by Lunin et al. in 1993, in which only $42 \%$ of females and $60 \%$ of males were aware of this fact [39]. In the same study, only $15 \%$ of the adolescents perceived themselves 'not at risk' of contracting HIV (Table 3).
Only one study reported asking the adolescents if one can tell by looking at someone if they have HIV, to which $47 \%$ responded affirmatively [43].

\section{Awareness and knowledge of chlamydia}

The proportion of adolescents able to identify chlamydia as an STD from a list of diseases ranged from $34 \%$ in the study conducted in England by Garside et al. [42] to $96 \%$ in the Swedish study by Andersson-Ellström et al. [22]. In the Garside study, the proportion was higher 
among year 9 than among year 11 pupils $(\mathrm{p}<0.05)$. In another Swedish study by Höglund et al. $86 \%$ of the surveyed adolescents mentioned chlamydia as one of the STDs known to them in response to an open question [47]. In the two studies which reported on awareness among boys and girls separately, girls were observed to have higher awareness proportions than boys [38,42]. While the observation was not statistically significant in one of the studies, [27] this was not reported on in the other study [38].

Not many adolescents knew that chlamydia can be symptom-free: 40\% and 56\% in the 1986 and 1988 surveys by Andersson-Ellström et al. [37] and 46\% in the study by Höglund et al. [47]. In one Swedish study where the level of knowledge in the same study population was assessed at age 16 and 18, a statistically significant increase in knowledge was observed over time [40]. Only the Finish study reported on the subjective rating of risk of contracting chlamydia. $55 \%$ of the adolescents surveyed reported 'low perceived susceptibility' [45] (Table 3).

\section{Awareness and knowledge of gonorrhoea}

Gonorrhoea was identified as an STD from a given list by $84 \%$ of adolescents in the survey by Tyden et al., [38] by 98\% in the survey by Andersson-Ellström et al., [37] and by $53 \%$ in the survey by Garside et al. [42]. In the latter, the difference between year 9 and year 11 pupils was more pronounced among boys: 53\% among year 9 and $60 \%$ among year 11 ( $\mathrm{p}>0.05)$. A statistically significant increase in knowledge over time was observed in a group of girls surveyed at age 16 and 18 [40]. Only $50 \%$ of the adolescents surveyed in the study by Höglund et al. mentioned gonorrhoea in response to an open question on known STDs [47] (Table 3).

\section{Awareness of syphilis and herpes}

Awareness of syphilis was surveyed only in the study conducted in England where 45\% of the participating adolescents correctly identified the disease from a given list as an STD. The proportion was slightly higher among year 11 compared to year 9 pupils and awareness was slightly higher among girls than among boys ( $\mathrm{p}>$ 0.05) [42] (Table 3).

In the Tyden et al. study, [38] 56\% of the surveyed adolescents identified herpes as an STD from a given list. The proportion was $90 \%$ in the survey by Andersson-Ellström et al. [37] and 59\% in the Garside et al. study [42]. In the latter, considerable differences were observed between year 9 and year 11 pupils $(\mathrm{p}<0.05)$, but not between girls and boys in the same school year. Herpes was mentioned as an STD by $64 \%$ of the adolescents surveyed in the study by Höglund et al. [47] (Table 3).

\section{Awareness of STDs in general}

Five of the studies reviewed assessed the knowledge of participating adolescents on STDs in general. In the England study, all in all 59.7\% of the participants knew that STDs in general can be symptom-free [42]. Among girls, knowledge was higher among year 11 than year 9 pupils, while the opposite was true for boys. The proportion of boys in year 9 who knew this fact $(64.2 \%)$ was considerably higher than that of year 9 girls (53.8\%) (Table 3). In two Swedish studies by Tyden et al. and by Andersson-Ellström et al., all surveyed adolescents knew that the use of condoms can protect against the contraction of STDs in general $[38,40]$. In an earlier study by Andersson-Ellström et al., 20\% of sexually active pupils surveyed in 1986 were aware that condoms protect against infection. The figure significantly went up to $43 \%$ in 1988, with boys having significantly higher awareness than girls in both years [22] (Table 3). In the same study, the proportion of girls who felt themselves to be at risk of contracting an STD in general went down from $32 \%$ in the 1986 survey to $24 \%$ in the 1988 survey. Among boys, the proportion increased from 16\% in 1986 to $24 \%$ in 1988 . These changes were not statistically significant [37]. In the Finish study, 55\% of the surveyed adolescents perceived themselves to be at low risk of contracting an STD [45].

\section{Reported use of condoms}

Use of condoms by sexually active participants was assessed in three studies, all conducted in Sweden $[38,46,47]$. Reported use at sexual debut was lowest in the study published in 1991 (31\%), [38] and higher in the other studies both published in 2009: 61\% [47] and 65\% [46] respectively (Table 3 ). In the earlier study, the proportion of girls reporting condom use was, at $50 \%$, considerably higher than that of boys (40\%) [38]. In the study by Gottvall et al., no difference in condom use was observed between girls and boys [46]. Condom use at recent coitus was reported on only in the earlier study [38]. It was observed that the decrease in the proportion of girls reporting using condoms was more pronounced than that of boys ( $26 \%$ vs. $40 \%$ ) (Table 3 ).

\section{Discussion}

The highest awareness and knowledge were reported for HIV/AIDS. This is certainly linked to the fact that since the mid 1980s, extensive awareness campaigns on this topic have been conducted globally. The lowest proportions were reported for HPV, with awareness as low as $5.4 \%$ in one study [47]. With only about 1 in 8 respondents knowing that HPV is an STD, awareness was still very low in one of the two studies conducted after the introduction of the HPV vaccine [46]. A higher awareness 
(66.6\% of respondents aware), measured in a different population, was observed in the second recent study on HPV [48].

Two factors appeared to have influenced awareness. The first was of a methodological nature and related to the fact whether an open or closed question was posed. Of the studies included in the review which assessed awareness, all but one used closed-form questions only. The adolescents either had to identify sexually transmitted diseases from a given list of diseases, or the question was in a yes/no format. Initially, Höglund et al. asked participating adolescents to list all STDs known to them and then later on, if they had ever heard of HPV. Only one participant (0.2\%) mentioned HPV as one of the STDs known to them, but later, 24 (5.4\%) reported to have heard of HPV [47]. In comparison to open-form questions, closed questions are not only more practical and easier to respond to, but also easier to code and analyse. One of the arguments raised against closed questions, especially where a list of possible answers is given, is the risk of guesswork. It can not be ruled out that some participants, unable to answer the question, will select answers at random [50,51]. In the study by Garside et al. for example, among year 9 pupils, $14.5 \%$ incorrectly identified plasmodium, and $20.6 \%$ filariasis from a given list as STDs [42]. Open questions have been recommended for surveying participants with unknown or varying knowledge/awareness [50] as these questions provide a more valid picture of the state of knowledge [51].

To a lesser extent, gender also appears to have influenced knowledge and awareness, especially for HPV $[46,48]$. Significant gender differences were observed, with females having better awareness and knowledge than males. Although the data are limited as not all studies reported results separately for males and females, these findings, could be reflective of the way awareness campaigns, for example on HPV, have been targeted more at females than at males.

The studies on HIV included in our review generally reported high awareness of the protective effect of condoms among adolescents $[36,41,43,47,49]$. One study included in the review however observed that adolescents seem to regard condoms primarily as a method of contraception and not as a means of protection against sexually transmitted diseases (40). In this study, 19 out of 20 female adolescents who reported more than 4 sexual partners at the age of 18 reported intercourse without a condom in relationships of less than 6 months' duration. The majority of them were, however, convinced that they had neither acquired (96\%) nor transmitted (93\%) an STD at last unprotected intercourse [40]. Other studies also indicate that consistent condom use is generally low among adolescents [27,52-55].
Where reported, participation rates were generally high, probably due to the fact that the adolescents were recruited in schools. In some instances however, the number of participants was low even though the participation rate was reported as high. In the study by Tyden et al. for example, the study sample consisted of 213 pupils, $12 \%$ of the 1830 students in the first form of upper secondary school in Uppsala [38]. The authors base the participation rate of their study (98\%) on the $12 \%$, without explaining how it came about that only 213 pupils were considered for participation. The one study which recruited participants per post had a very low participation rate of $21.5 \%$ [45]. Nevertheless, the study had more participants than others with comparatively higher participation rates. Bias related to selective participation is an issue that needs to be considered on a study by study basis, and reporting on response proportions should be considered essential for all studies.

\section{Study strengths and limitations}

To our knowledge no systematic reviews of published literature on knowledge and awareness of sexually transmitted diseases among school-attending adolescents in Europe have been conducted to date. The current review confirms that there are considerable gaps in knowledge and awareness on major STDs in European adolescents. Our results underline the importance of the objectives set for adolescents' sexual and reproductive health in Europe, the first of which foresees that adolescents be informed and educated on all aspects of sexuality and reproduction [31].

We could not identify many studies on knowledge and awareness of sexually transmitted diseases among schoolattending adolescents in Europe. This could be due to the fact that knowledge has been shown to have little impact on behaviour change, and prevention interventions have generally moved away from a focus on knowledge and awareness as key mediators. Another possible reason is that schools are not always willing to participate in such studies due to competing demands of other school activities or because of the subject content [16,28-30].

One limitation of our review is that the 15 studies included did not all focus on the same sexually transmitted diseases. The four studies conducted in Eastern Europe were all on HIV/AIDS knowledge and awareness only, whereas Western European studies were on STDs in general or on HPV. Furthermore, the formulation of the questions used to assess awareness and knowledge varied between studies, making it difficult to directly compare the findings of individual studies. Another potential limiting factor is the age variation of participants in the studies included in the review, especially as all but one study did not clearly investigate the association between age and awareness or knowledge. Due to the afore-mentioned factors and the small number of studies available, it was not possible to perform a meta-analysis of the study findings. 
The representativeness of study participants in some studies could not be assessed as it was not mentioned how the schools were selected [37,40-44,49]. Different socioeconomic environments of individual schools are likely to affect results, but there is currently not sufficient information to assess this.

The school setting offers an effective way to access adolescent populations universally, comprehensively and uniformly [56]. It plays an important role for sex education, especially for those adolescents with no other information sources. Furthermore, some parents are not comfortable discussing sexual issues with their children. It therefore comes as no surprise that many young people cite the school as an important source of information about sexually transmitted diseases [26,27]. Although sex education is part of the school curriculum in many European countries, there are differences in the issues focused on. In some countries sex education is integrated in life skills approach, whilst biological issues are predominant in others and at times the focus is on HIV/AIDS prevention [57]. Generally it seems that education schedules offer a range of opportunities to raise knowledge and awareness of STD among adolescents.

\section{Conclusion}

In general, the studies reported similar low levels of knowledge and awareness of sexually transmitted diseases, with the exception of HIV/AIDS. Although, as shown by some of the findings on condom use, knowledge does not always translate into behaviour change, adolescents' sex education is important for STD prevention, and the school setting plays an important role. Beyond HIV/AIDS, attention should be paid to infections such as chlamydia, gonorrhoea and syphilis.

\section{Additional material}

Additional file 1: Review Protocol: The preparation process for the systematic review is documented in the file. Included are the objectives of the review, inclusion and exclusion criteria, the search strategy, definition of outcomes, as well as the data abstraction table.

\section{Authors' contributions}

FSZ developed the concept for the study, conducted the literature search, assessed studies for inclusion in the review and extracted data. She also prepared drafts and undertook edits. LS was involved in the development of the study concept, conducted the literature search, assessed studies for inclusion in the review and extracted data. $\mathrm{HZ}$ was involved in the development of the study concept. All authors contributed to the editing of the drafts and have read and approved all versions of the manuscript.

\section{Competing interests}

The authors declare that they have no competing interests.

Received: 12 May 2011 Accepted: 25 September 2011 Published: 25 September 2011
References

1. World Health Organisation: Global prevalence and incidence of selected curable sexually transmitted infections. WHO, Geneva; 2001.

2. Panchaud C, Singh S, Feivelson D, Darroch JE: Sexually transmitted diseases among adolescents in developed countries. Fam Plan Persp 2000, 32:24-32 \&45, Last accessed 30.11.2010.

7. Adler MW: Sexually transmitted infections in Europe. Eurohealth 2006, 12:3-6.

8. PHLS, DHSS \& PS and the Scottish ISD(D)5 Collaborative Group: Trends in Sexually Transmitted Infections in the United Kingdom 1990-1999. Public Health Laboratory Service London; 2000.

9. Stamm W, Guinan M, Johnson C: Effect of treatment regiments for Neisserie gonorrhoea on simultaneous infections with Chlamydia trachomatis. New Eng J Med 1984, 310:545-559.

10. MacDonald NE, Brunham R: The Effects of Undetected and Untreated Sexually Transmitted Diseases: Pelvic Inflammatory Disease and Ectopic Pregnancy in Canada. The Canadian Journal of Human Sexuality 1997, 6(2): Special Issue: STDs and Sexual/Reproductive Health, online publication: last accessed 03.12.2010.

14. Ross J, Godeau E, Dias S: Sexual health. In Young people's health in context. Health Behaviour in School-aged Children (HSBC) study: International report from the 2001/2002 survey. Edited by: Currie C, Roberts C, Morgan A, et al. Copenhagen: WHO; 2004:.

15. Bundeszentrale für gesundheitliche Aufklärung: Jugendsexualität. Repräsentative Wiederholungsbefragung von 14- bis 17-Jährigen Jugendlichen und ihren Eltern. BZgA; 2006.

16. Tucker JS, Fitzmaurice AE, Imamura M, Penfold S, Penney GC, van Teijlingen E, Schucksmith J, Philip KL: The effect of the national demonstration project Healthy Respect on teenage sexual health behaviour. Eur J Public Health 2006, 17(1):33-41.

17. Godeau E, Gabhainn SN, Vignes C, Ross J, Boyce W, Todd J: Contraceptive use by 15 -year-old students at their last sexual intercourse: Results from 24 countries. Arch Paediatr Adolesc Med 2008, 162:66-73.

18. Bundeszentrale für gesundheitliche Aufklärung: Sexualität und Migration: Milieuspezifische Zugangswege für die Sexualaufklärung Jugendlicher. Ergebnisse einer repräsentativen Untersuchung der Lebenswelten von 14- bis 17-Jährigen Jugendlichen mit Migrationshintergrund. BZgA; 2010.

19. Heinz M: Sexuell übertragbare Krankheiten bei Jugendlichen: Epidemiologische Veränderungen und neue diagnostische Methoden. Arbeitsgemeinschaft Kinder-und Jugendgynäkologie e.V; 2001 [http://www. kindergynaekologie.de/html/kora22.html], last accessed 03.12.2010.

20. Berrington de González A, Sweetland S, Green J: Comparisons of risk factors for squamous cell and adenocarcinomas of the cervix: a metaanalysis. Br J Cancer 2004, 90:1787-1791.

21. Reich O: Is early first intercourse a risk factor for cervical cancer? Gynäkol Geburtshilfliche Rundsch 2005, 45:251-256.

22. Gille G, Klapp C: Chlamydia trachomatis infections in teenagers. Der Hautarzt 2007, 58:31-37.

23. Hwang LY, Ma Y, Miller Benningfield S, Clayton L, Hanson EN, Jay J, Jonte J, Godwin de Medina C, Moscicki AB: Factors that influence the rate of epithelial maturation in the cervix of healthy young women. J Adolesc Health 2009, 44(2):103-110.

24. Kegeles SM, Adler NE, Irwin CE: Adolescents and condoms. Am J Dis Child 1989, 143:911-915.

25. Ford N: The AIDS awareness and sexual behaviour of young people in the South-west of England. J Adolesc 1992, 15:393-413.

26. Persson E, Sandströäm B, Jarlbro G: Sources of information, experiences and opinions on sexuality, contraception and STD protection among young Swedish students. Advances in Contraception 1992, 8:41-49.

27. Editorial team: Young people's knowledge of sexually transmitted infections and condom use surveyed in England. Euro Surveill 2005, 10(31): pii $=2766$, Last accessed 30.11.2010.

28. Lister-Sharpe D, Chapman S, Stewart-Brown S, Sowden A: Health promoting schools amd health promotion in schools: two systematic reviews. Health Technol Assess 1999, 3(22):1-207.

29. Wight D, Raab G, Henderson M, Abraham C, Buston K, Hart G, Scott S: Limits of teacher delivered sex education: interim behavioural outcomes from randomised trial. BMJ 2002, 324:1-6.

30. Stephenson J, Strange V, Forrest S, Oakley A, Copas A, Allen E, Babiker A, Black S, Ali M, Monteiro H, Johnson AM: Pupil-led sex education in 
England (RIPPLE study): cluster randomised intervention trial. Lancet 2004, 364(9431):338-346.

31. WHO Regional Office for Europe: Who Regional Strategy on Sexual and Reproductive Health. 2001 [http://www.euro.who.int/_data/assets/ pdf_file/0004/69529/e74558.pdf], pdf last accessed 17.03.2011.

32. Bundeszentrale für gesundheitliche Aufklärung: Country papers on youth sexuality in Europe - Synopsis. BZgA; 2006

33. Bobrova N, Sergeev O, Grechukhina T, Kapiga S: Social-cognitive predictors of consistent condom use among young people in Moscow. Perspect Sex Reprod Health 2005, 37(4):174-178.

34. European Commission: Compulsory education in Europe 2010/2011. [http://eacea.ec.europa.eu/education/eurydice/documents/ compulsory_education/compulsory_education.pdf], pdf last accessed 10.05.2011.

35. Assessing scientific admissibility and merit of published articles: Critical appraisal form. [http://peds.stanford.edu/Tools/documents/ Critical_Appraisal_Form_CGP.pdf], last accessed 08.03.2011.

36. Fogarty J: Knowledge about AIDS among leaving certificate students. Irish Med Journal 1990, 83:19-21.

37. Andersson-Ellström A, Forssman L: Sexually transmitted diseases knowledge and attitudes among young people. J Adolesc Health 1991, 12:72-76.

38. Tyden T, Norden L, Ruusuvaara L: Swedish students' knowledge of sexually transmitted diseases and their attitudes to the condom. Midwifery 1991, 7:25-30.

39. Lunin I, Hall TL, Mandel JS: Adolescent sexuality in Saint Petersburg, Russia. AIDS 1995, 9(suppl 1):S53-S60.

40. Andersson-Ellström A, Forssman L, Milsom I: The relationship between knowledge about sexually transmitted diseases and actual sexual behaviour in a group of teenage girls. Genitourin Med 1996, 72:32-36.

41. Eriksson T, Sonesson A, Isacsson A: HIV/AIDS - information and knowledge: a comparative stud of Kenyan and Swedish teenagers. Scand J Soc Med 1997, 25:111-118.

42. Garside R, Ayres R, Owen M, Pearson VAH, Roizen J: 'They never tell you about the consequences': young people's awareness of sexually transmitted infections. Int J STD \& AIDS 2001, 12:582-588.

43. Goodwin R, Kozlova A, Nizharadze G, Polyakove G: HIV/AIDS among adolescents in Eastern Euorpe: knowledge of HIV/AIDS, social representations of risk and sexual activity among school children and homeless adolescents in Russia, Georgia and the Ukraine. J Health Psych 2004, 9:381-396.

44. Macek M, Matkovic V: Attitudes of school environment towards integration of HIV-positive pupils into regular classes and knowledge about HIV/AIDS: cross-sectional study. Croat Med J 2005, 26:320-325.

45. Woodhall $\mathrm{Sc}$, Lehtinen M, Verho $\mathrm{T}$, Huhtala H, Hokkanen M, Kosunen E: Anticipated acceptance of HPV vaccination at the baseline of implementation: a survey of parental and adolescent knowledge and attitudes in Finland. J Adolesc Health 2007, 40:466-469.

46. Gottvall M, Larsson M, Högkund AT, Tydén T: High HPV vaccine acceptance despite low awareness among Swqedish upper secondary school students. Eur J Contr Repr Health Care 2009, 14:399-405.

47. Höglund AT, Tydén T, Hannerfors AK, Larsson M: Knowledge of human papillomavirus and attitudes to vaccination among Swedish high school students. Int J STD \& AIDS 2009, 20:102-107.

48. Pelucchi C, Esposito S, Galeone C, Semino M, Sabatini C, Picciolli I, Consolo S, Milani G, Principi N: Knowledge of human papillomavirus infection and its prevention among adolescents and parents in the greater Milan area, Northern Italy. BMC Public Health 2010, 10:378.

49. Sachsenweger M, Kundt G, Hauk G, Lafrenz M, Stoll R: Knowledge of school pupils about the HIV/AIDS topic at selected schools in Mecklenburg-Pomerania: Results of a survey of school pupils. Gesundheitswesen 2010, online publication 2.3.2010 [http://dx.doi.org/ 10.1055/s-0029-1246199], Last accessed 02.05.2011.

52. Piccinino $\sqcup$, Mosher WD: Trends in contraceptive use in the United States: 1982-1995. Family Planning Perspectives 1998, 30:4-10.

53. Glei DA: Measuring contraceptive use patterns among teenage and adult women. Family Planning Perspectives 1999, 31:73-80.

54. Everett SA, Warren CW, Santelli JS, Kann L, Collins IL, Kolbe LJ: Use of birth control pills, condoms and withdrawal among U.S. high school students. Journal of Adolescent Health 2000, 27:112-118.
55. Kaaya SF, Flisher AJ, Mbwambo JK, Schaalma H, Aaro LE, Klepp KI: A review of studies of sexual behaviour of school students in sub-Saharan Africa. Scandinavian Journal of Public Health 2002, 30:148-160.

56. Abraham C, Wight D: Developing HIV-preventive behavioural interventions for young people in Scotland. Int Journal of STD and AIDS 1996, 7(suppl 2):39-42.

57. Helfferich C, Heidtke B: Country papers on youth sex education in Europe. BZgA; 2006.

\section{Pre-publication history}

The pre-publication history for this paper can be accessed here: http://www.biomedcentral.com/1471-2458/11/727/prepub

doi:10.1186/1471-2458-11-727

Cite this article as: Samkange-Zeeb et al:: Awareness and knowledge of sexually transmitted diseases (STDs) among school-going adolescents in Europe: a systematic review of published literature. BMC Public Health 2011 11:727.

\section{Submit your next manuscript to BioMed Central and take full advantage of:}

- Convenient online submission

- Thorough peer review

- No space constraints or color figure charges

- Immediate publication on acceptance

- Inclusion in PubMed, CAS, Scopus and Google Scholar

- Research which is freely available for redistribution

Submit your manuscript at www.biomedcentral.com/submit
Biomed Central 